\title{
STATUS, NEEDS, AND KNOWLEDGE LEVELS OF MISSISSIPPI'S COMMUNITIES RELATIVE TO URBAN FORESTRY
}

\author{
Stephen C. Grado, Donald L. Grebner, Marcus K. Measells, and Amanda L. Husak
}

\begin{abstract}
There is a need to determine levels of knowledge about and participation in urban and community forestry programs by local elected officials and other community planners. This project's goals were to identify the past and current involvement and future interest levels among Mississippi's small to large communities for urban forestry programs and assistance. A mail survey was sent to 296 Mississippi, U.S., communities. There were 159 surveys returned for a response rate of $53.7 \%$. In general, the survey sample of Mississippi's communities indicated that a sizable number of officials have little or no awareness or interest in urban and community forestry. Among the Mississippi communities that wanted to establish urban and community forestry programs, most cited a lack of funding as the reason for not initiating projects or sustaining existing programs. Greater effort in disseminating information on funding opportunities is necessary, given that most Mississippi communities were aware of only a few national programs. Participation in statewide or local programs was minimal. Without good information and reliable funding, communities are limited in undertaking systematic planning and associated programs for tree resources in their community. In addition, effectively delivering information to communities to broaden public appreciation of urban forest resources is critical.

Key Words. Community planners; governmental agencies; large communities; Mississippi; program assessment; small communities; survey research; urban and community forestry.
\end{abstract}

Implementing urban and community forestry activities is an important consideration for any community. In a wellmanaged program, a community can derive many social and economic benefits from the urban forest. Some of the more commonly known benefits are improved aesthetics, increased real estate values, noise pollution reduction, and improved air and water quality (Dwyer et al. 1992). A healthy urban forest can be more cost effective than many of the other fuel-saving methods available in managing energy consumption levels and reducing carbon dioxide (Dwyer et al. 1992). Monetary benefits can be achieved by strategically placing trees around a building to reduce airconditioning use during summer (McPherson 1996). Other lesser known but equally important benefits are increased life expectancy of pavement and control of stormwater runoff (yielding a decrease in flooding and erosion problems within the community) (Maco and McPherson 2002).
Not all community or government leaders, however, have a clear and thorough understanding of urban and community forestry. Reasons for this lack of understanding may be traced to an information gap on the subject or absence of educational resources. Information that is well understood and correctly carried forth can lead to a successful tree care program that is continually cost effective. However, if little is known about tree care, then the lack of a program, or mistakes generated in implementing one, can incur greater costs and reduce benefits (Dwyer et al. 1992).

A study in Wisconsin found a strong correlation between the presence of a university or college and an urban forestry program in the same town or city (Miller and Bate 1978). This finding was attributed to the assumption that information and other educational materials on tree care were readily available for the community and public from these institutions (Miller and Bate 1978).

There are communities familiar with many of the options that urban and community forestry can provide, but not all are actively managing their urban forest resources. Even when they are managing their resources, ineffectiveness can sometimes be caused by an idle or improperly managed program (Grey 1978). Population size, which influences the amount of taxes available to a community, can also influence the potential for instituting urban forestry activities (Miller and Bate 1978). In a 12-city case study in the United States, an unsuccessful urban forestry program was attributed to a lack of funding and city budgeting (Johnson 1982). Urban forestry programs continually compete for funding from the city budget and are often ignored in favor of more essential services (e.g., police protection or fire control) (Tate 1982).

In a Wisconsin study, government leaders felt that more developmental activities in urban forestry programs would have occurred if outside governmental assistance had been provided to their city or town (Miller and Bate 1978). In these cases, government funding in the form of grants was needed; however, finding available grants was the issue. Tate (1982) found that two-thirds of communities surveyed within the United States felt they had insufficient information to apply for grants, and a portion of these communities did not know of any potential sources of funding. Almost all surveyed communities claimed they would apply for funding 
if information were available about the application process (Tate 1982).

More recent studies, such as Elmendorf et al. (2003) and Treiman and Gartner (2004), found similar trends in Missouri and Pennsylvania. Elmendorf et al. (2003) found that $39 \%$ of municipal tree programs were adequately funded from general revenue sources, while only $21 \%$ of all communities thought their municipality's funding was enough to function effectively. Only 23\% of these communities conducted external fund-raising to alleviate their budgetary shortfalls. Treiman and Gartner (2004) found that $52 \%$ of all Missouri communities provided no budgetary support for urban and community forestry projects, while $54 \%$ of respondents felt that they were not receiving adequate financial resources to manage their programs.

To address these issues in Mississippi, further research was necessary to assess current programs across large and small communities. A community was defined as a municipality having local self-government. The study's focus was to identify the existence of current programs and examine communities where no programs exist. For both, knowledge levels about opportunities to gain information or take advantage of outreach programs and finding funding sources were of prominent importance. No previous work of this type has been done in the past.

The study's main objective was to identify community needs and issues relative to urban forestry (specifically, major challenges such as water quality and flooding), the knowledge level of community leaders (e.g., urban forestry program identification, funding sources), future research areas, programs already in place and their success levels, and vehicles used to both obtain funding for existing programs and for their implementation. This type of detailed information is currently unknown to those who are interested in promoting urban and community forestry. In addition, uncovering this information and distributing it to governmental leaders and agencies, communities, professionals (e.g., community planners) and nonprofessionals in urban forestry, and the general public will enable the initiation and/or promotion of urban and community forestry activities, projects, and programs.

\section{METHODS}

A literature review was conducted to synthesize existing applicable materials and information to develop a survey questionnaire. Mississippi State University researchers developed all survey questions to determine the success of existing community programs and intentions directed toward future programs and opportunities. Upon completion of this internal review, a pilot survey was sent to eight Mississippi communities to further determine its effectiveness. All eight communities returned a completed survey.
Discovery and documentation of pertinent information and other associated data related to urban and community forestry issues cannot occur without contacting governmental entities and other personnel (e.g., community planners) responsible for initiating, promoting, and implementing urban and community forestry projects in their locales. Therefore, we had to identify potential survey participants by collecting names and addresses that were accessible through the public domain. Specifically, survey respondents consisted of key members of city and town governments, municipal governments, and community planners (e.g., mayors, county clerks, urban foresters, land planners, public works directors, parks and recreation directors, and public safety departments). In all cases, communities were contacted by telephone prior to mailing the survey instrument to make sure the appropriate individual would receive the survey. Also, the executive director of the Mississippi Urban Forestry Council (MUFC) sent a letter of introduction announcing the forthcoming survey.

Surveys were accompanied by a cover letter explaining confidentiality, project goals, and end products. The formal survey process (Dillman 2000) consisted of mailing out the survey on 14 June 2004, and then 1 week later sending a thank-you or reminder postcard. Three weeks after mailing the initial survey, a second survey was mailed, on 5 July 2004. Finally, a third survey was mailed 3 weeks later, on 28 July 2004. Survey responses were tabulated and analyzed upon return.

\section{RESULTS}

A total of 296 communities were represented on the mailing list. Of these 296, 186 communities had fewer than 2,000 inhabitants, 73 had between 2,000 and 10,000, and 37 had more than 10,000. All surveys were deliverable. There were 159 surveys returned for an overall response rate of $53.7 \%$. The response rate was $46.8 \%$ for communities with fewer than 2,000 inhabitants, $54.8 \%$ for communities having between 2,000 and 10,000 inhabitants, and $86.5 \%$ for communities with more than 10,000 inhabitants.

Results from the survey process were summarized and provided information on community familiarity with urban and community forestry, need and interest for local programs, past experiences, problems in implementing and maintaining urban and community forestry programs, awareness of resources and funding opportunities, and categorization of existing programs. As important, this study collected community preferences for receiving important resource materials.

\section{Familiarity with Urban and Community Forestry}

Mississippi communities were asked whether they were familiar with the term "urban and community forestry." Of the responding communities, $48.3 \%(n=42)$ of those with 
fewer than 2,000 inhabitants indicated an awareness of the terminology, whereas $50.6 \%(n=44)$ did not. For communities with 2,000 to 10,000 inhabitants, $72.5 \%(n=29)$ were familiar with the terminology, while $27.5 \%(n=11)$ were not. For communities with more than 10,000 inhabitants, $87.5 \%$ $(n=28)$ were familiar with the term "urban and community forestry."

Surveyed communities who were aware of urban and community forestry were then asked to make multiple selections from among 31 categories to assess topics of familiarity. There was a wide array of responses. The five highest categories of familiarity pertained to erosion reduction (46.5\%), wildlife habitat (43.4\%), aesthetic features (43.4\%), recreation (42.8\%), and air quality (42.8\%). Variations in community awareness for the multiple benefits of urban and community forestry by municipality size are shown in Table 1. For those five categories of familiarity, communities with fewer than 2,000 inhabitants had an awareness of the multiple benefits derived from urban and community forestry programs ranging from $24 \%$ to $36 \%$, whereas communities with more than 10,000 people demonstrated a $71 \%$ to $82 \%$ familiarity with those benefits.

\section{Need and Interest in Establishing an Urban Forestry Program}

Information was also collected on the need and interest expressed by municipalities in establishing an urban and community forestry program. Of the respondents, $73.6 \%$ indicated a need for urban and community forestry projects in their municipality. Only 6.3\% did not see a need, while $20.1 \%$ did not or were unable to answer the question. This may be due, in part, to their unfamiliarity with urban and community forestry programs.

In collecting information on community interest in establishing an urban and community forestry project or program, the survey asked potential respondents to rank their interest on a scale from 1 to 5 , where 1 indicated not very interested and 5 indicated very interested (Table 2). Of the surveyed communities, 53.4\% indicated an avid interest and enthusiasm for starting new projects or programs, whereas $12.6 \%$ tended to not be interested. However, $31.4 \%$ of responding communities were ambivalent about having an urban and community forestry program started in their locale.

When disaggregating the data by community size, there was a clear trend suggesting that larger communities have a stronger interest in promoting urban and community forestry projects. For instance, only $39.1 \%$ of communities with fewer than 2,000 inhabitants showed a strong interest in promoting urban forestry projects. Responses from larger communities $(78.2 \%)$ showed a stronger interest in these projects. community size $(n=159)$.

\begin{tabular}{|c|c|c|c|c|}
\hline Inhabitants & $\begin{array}{l}<2,000 \\
\text { count }(\%)\end{array}$ & $\begin{array}{l}2,000-10,000 \\
\text { count }(\%)\end{array}$ & $\begin{array}{l}>10,000 \\
\text { count }(\%)\end{array}$ & $\begin{array}{l}\text { Total } \\
\text { count (\%) }\end{array}$ \\
\hline \multicolumn{5}{|l|}{ Erosion reduction } \\
\hline Aware & $31(35.6)$ & $17(42.5)$ & $26(81.3)$ & $74(46.5)$ \\
\hline Unaware & $12(13.8)$ & $12(30.0)$ & $3(9.4)$ & $27(17.0)$ \\
\hline Not applicable & $44(50.6)$ & $11(27.5)$ & $3(9.4)$ & $58(36.5)$ \\
\hline \multicolumn{5}{|l|}{ Wildlife habitat } \\
\hline Aware & $30(34.5)$ & $14(35.0)$ & $25(78.1)$ & $69(43.4)$ \\
\hline Unaware & $13(14.9)$ & $15(37.5)$ & $4(12.5)$ & $32(20.1)$ \\
\hline Not applicable & $44(50.6)$ & $11(27.5)$ & $3(9.4)$ & $58(36.5)$ \\
\hline \multicolumn{5}{|l|}{ Aesthetics } \\
\hline Aware & $21(24.1)$ & $22(55.0)$ & $26(81.3)$ & $69(43.4)$ \\
\hline Unaware & $22(25.3)$ & $7(17.5)$ & $3(9.4)$ & $32(20.1)$ \\
\hline Not applicable & $44(50.6)$ & $11(27.5)$ & $3(9.4)$ & $58(36.5)$ \\
\hline \multicolumn{5}{|l|}{ Recreation } \\
\hline Aware & $27(31.0)$ & $18(45.0)$ & $23(71.9)$ & $68(42.8)$ \\
\hline Unaware & $16(18.4)$ & $11(27.5)$ & $6(18.8)$ & $33(20.8)$ \\
\hline Not applicable & $44(50.6)$ & $11(27.5)$ & $3(9.4)$ & $58(36.5)$ \\
\hline \multicolumn{5}{|l|}{ Air quality } \\
\hline Aware & $24(27.6)$ & $20(50.0)$ & $24(75.0)$ & $68(42.8)$ \\
\hline Unaware & $19(21.8)$ & $9(22.5)$ & $5(15.6)$ & $33(20.8)$ \\
\hline Not applicable & $44(50.6)$ & $11(27.5)$ & $3(9.4)$ & $58(36.5)$ \\
\hline
\end{tabular}

\section{Urban and Community Forestry Experiences}

The study also surveyed communities on their past experiences with urban and community forestry programs to form a basis for assessing historical efforts in Mississippi. Of those responding to this question, only $31.4 \%$ had initiated an urban and community forestry project or program prior to receiving this survey. Forty-four percent of communities had no experience with urban and community forestry projects. Four communities had projects or programs, but they were discontinued. In some cases, these projects or programs simply may have been completed rather than dropped. The remaining $22.1 \%$ either did not know whether they had projects in the past, or they did not respond to this question.

Of communities with experience in urban and community forestry projects prior to this survey, only 45 responded to 
the question concerning years of involvement with urban and community forestry projects or programs. Their involvement ranged from 1 to 25 years, with a fairly uniform distribution. Twelve communities provided a variety of reasons for having discontinued projects or programs. Reasons for program termination included lack of funding and resources, waning local interest, and project completion.

Another question queried communities about whether they employed an urban or community forester, firm, or similar specialist. Of communities responding to the survey, $50.9 \%$ said no, $8.2 \%$ indicated they had one, and $10.1 \%$ did not respond to this question. Forty-nine communities skipped this question, perhaps because they had never initiated any projects or programs. Among the 13 communities (14 replied) with an urban or community forester, several had cooperative partnerships with other communities to handle their urban forest, or they employed a landscape architect. Only one community stated that they employed a full-time urban forester.

When communities were asked whether they intended to hire an urban or community forester, firm, or similar specialist in the future, only $12.2 \%$ indicated an intent to do so, while $53.7 \%$ had no intention. Twenty-eight communities were still debating the issue; however, 77 communities did not respond or indicated the question was not applicable. Of communities that intended to hire in the future, there was a wide array of responses as to the type of employee

Table 2. Interest in promoting local urban and community forestry projects and programs $(n=159)$ as indicated by community leaders in Mississippi by community size during 2004, where 1 indicates least interest and 5 most interest.

\begin{tabular}{lcccc}
\hline Inhabitants & $\begin{array}{l}<, 000 \\
\text { count (\%) }\end{array}$ & $\begin{array}{l}2,000-10,000 \\
\text { count (\%) }\end{array}$ & $\begin{array}{l}>10,000 \\
\text { count (\%) }\end{array}$ & $\begin{array}{l}\text { Total } \\
\text { count (\%) }\end{array}$ \\
\hline 1 (least interest) & $8(9.2)$ & $1(2.5)$ & $0(0.0)$ & $9(5.7)$ \\
2 & $10(11.5)$ & $1(2.5)$ & $0(0.0)$ & $11(6.9)$ \\
3 & $32(36.8)$ & $12(30.0)$ & $6(18.8)$ & $50(31.4)$ \\
4 & $12(13.8)$ & $13(32.5)$ & $7(21.9)$ & $32(20.1)$ \\
5 (most interest) & $22(25.3)$ & $13(32.5)$ & $18(56.3)$ & $53(33.3)$ \\
Did not answer & $3(3.4)$ & $0(0.0)$ & $1(3.1)$ & $4(2.5)$ \\
\hline
\end{tabular}

Table 3. Intentions to initiate any future urban and community forestry projects or programs in the near future as indicated by community leaders in Mississippi by community size during 2004 $(n=159)$.

\begin{tabular}{llcrl}
\hline & $<2,000$ & $2,000-10,000$ & $>10,000$ & Total \\
Inhabitants & count $(\%)$ & count $(\%)$ & count $(\%)$ & count (\%) \\
\hline Yes & $17(19.5)$ & $18(45.0)$ & $20(62.5)$ & $55(34.6)$ \\
No & $17(19.5)$ & $6(15.0)$ & $2(6.3)$ & $25(15.7)$ \\
Undecided & $52(59.8)$ & $16(40.0)$ & $9(28.1)$ & $77(48.4)$ \\
Did not answer & $1(1.1)$ & $0(0.0)$ & $1(3.1)$ & $2(1.3)$ \\
\hline
\end{tabular}

they would hire. For instance, communities expressed interest in hiring a part- or full-time urban forester, landscape architect, land-use planner, or arborist to meet their urban and community forestry needs.

Although several communities did not have existing urban or community forestry programs, several (34.6\%) indicated a desire to implement one in the future (Table 3). However, $15.7 \%$ did not intend to implement a program, while $48.4 \%$ of communities were still considering the option. Only 1.3\% did not respond to this question.

Examination of responses by community size indicated that $62.5 \%$ of larger communities, those with more than 10,000 inhabitants, intended to initiate urban and community forestry projects compared to only $19.5 \%$ of communities with fewer than 2,000 inhabitants. For moderately sized communities (2,000 to 10,000 inhabitants), 45\% intended to initiate these types of projects.

\section{Implementing and Maintaining Urban Forestry Programs}

One concern was to examine the factors that communities considered a hindrance in adopting an urban or community forestry program. These factors were information, funding, technical expertise, budget restrictions, staffing limitations, administrative support, community support, and logistical issues. Surveyed communities considered the impact of each factor on adopting an urban and community forestry program by ranking each on a scale from 1 to 5 , with 1 indicating the greatest hindrance and 5 indicating the least hindrance. In addition, this study also asked communities — whether they had a program or not-to identify which of the same factors were most important.

Lack of funding from outside sources for program development was a major hindrance to $44.7 \%(n=71)$ of surveyed communities. Few respondents $(0.6 \%, n=1)$ considered it somewhat of an obstacle in implementing a project, while 4.4\% $(n=7)$ did not. However, 15.1\% $(n=24) \mathrm{did}$ not respond to this question. Almost $75 \%(n=119)$ of communities felt that funding was somewhat or the most important factor in addressing urban and community forestry program needs, whereas only 6.3\% ( $n=10)$ did not. Approximately 14.0\% ( $n=$ 22) did not respond to this question.

Budgetary restrictions (i.e., internal budgeting from general funds) were considered an important factor in urban and community forestry program adoption. Almost half of the communities (39.6\%, $n=63)$ felt that this was the greatest hindrance to program adoption, whereas only 3.8\% $(n=6)$ felt it was the least hindrance. Almost 18.0\% $(n=28)$ did not respond to this question. Approximately half of 
the communities ( $48.4 \%, n=77$ ) felt budgetary restrictions were the most important need, whereas $4.4 \%(n=7)$ did not. However, 18.2\% $(n=29)$ did not respond to this question.

This study examined whether communities felt staffing limitations impacted their adoption of urban and community forestry programs. While $32.7 \%(n=52)$ of surveyed communities felt this was the greatest hindrance to program adoption, $10.7 \%(n=17)$ indicated it was somewhat of a hindrance, and 2.5\% ( $n=4)$ said it had little effect on program adoption. Several $(20.1 \%, n=32)$ did not respond to this question. The perception of staffing limitations by communities as a problem was clearly an issue: $39.6 \%(n=$ 63) of the communities viewed it as very important, while $19.5 \%(n=31)$ felt it was somewhat important. Only 3.8\% $(n=$ 6) did not view it as a hindrance. Approximately $18.0 \%(n=$ 28) did not respond to this question.

Breaking down the response data by community size indicated that $55.2 \%$ communities with fewer than 2,000 inhabitants found it more difficult to adopt an urban and community forestry program compared to $25 \%$ of communities with more than 10,000 people. This trend was consistent for responses by community size for budget restrictions and staffing limitations. Whether communities have an urban and community forestry program or not, approximately $72 \%$ of communities with more than 2,000 people indicated that funding had the greatest importance. Although the importance placed on budgetary restrictions followed a similar pattern, staffing limitations showed little difference in importance across community size.

\section{Awareness of Urban and Community Forestry Resources and Funding Opportunities}

Surveyed communities responded to general questions regarding their awareness of urban and community forestry resources. A majority of surveyed communities were aware of Arbor Day $(67.9 \%, n=108)$ and the Mississippi Forestry Commission (MFC) $(57.9 \%, n=92)$. A portion of this awareness has come from their association with MUFC. Earth Day was identified by $55.3 \%(n=88)$ of the surveyed communities. Other resources or programs highly identified were the Tree City USA program $(49.1 \%, n=78)$, the Transportation Enhancement Tree Planting program (T-21 money) $(30.2 \%, n=48)$, and the Urban and Community Forestry Assistance Challenge Grants programs $(23.3 \%, n=37)$. Other programs or resources such as Champion Trees, the Mississippi Urban Forestry Council, the National Urban Forestry Council, and the National Tree Trust were not
Table 4. Awareness of funding sources for urban and community forestry projects or programs as indicated by community leaders in Mississippi by community size during $2004(n=159)$.

\begin{tabular}{|c|c|c|c|c|}
\hline Inhabitants & $\begin{array}{l}<2,000 \\
\text { count }(\%)\end{array}$ & $\begin{array}{l}2,000-10,000 \\
\text { count }(\%)\end{array}$ & $\begin{array}{l}>10,000 \\
\text { count }(\%)\end{array}$ & $\begin{array}{l}\text { Total } \\
\text { count (\%) }\end{array}$ \\
\hline \multicolumn{5}{|c|}{ Federal Cooperative Forestry Assistance Grants } \\
\hline Aware & $11(12.6)$ & $7(17.5)$ & $8(25.0)$ & $26(16.4)$ \\
\hline Unaware & $75(86.2)$ & $33(82.5)$ & $24(75.0)$ & $132(83.0)$ \\
\hline Did not answer & $1(1.1)$ & $0(0.0)$ & $0(0.0)$ & $1(0.6)$ \\
\hline \multicolumn{5}{|c|}{ Urban and Community Forestry Assistance Challenge Grants } \\
\hline Aware & $9(10.3)$ & $14(35.0)$ & $23(71.9)$ & $46(28.9)$ \\
\hline Unaware & $77(88.5)$ & $26(65.0)$ & $9(28.1)$ & $112(70.4)$ \\
\hline Did not answer & $1(1.1)$ & $0(0.0)$ & $0(0.0)$ & $1(0.6)$ \\
\hline
\end{tabular}

Transportation Enhancement Tree Planting Program (T-21)

\begin{tabular}{|c|c|c|c|c|}
\hline Aware & $14(16.1)$ & $18(45.0)$ & $25(78.1)$ & $57(35.8)$ \\
\hline Unaware & $72(82.8)$ & $22(55.0)$ & $7(21.9)$ & $101(63.5)$ \\
\hline Did not answer & $1(1.1)$ & $0(0.0)$ & $0(0.0)$ & $1(0.6)$ \\
\hline \multicolumn{5}{|c|}{ Partnership Enhancement Monetary Grants } \\
\hline Aware & $3(3.4)$ & $1(2.5)$ & $3(9.4)$ & $7(4.4)$ \\
\hline Unaware & $83(95.4)$ & $39(97.5)$ & $29(90.6)$ & $151(95.0)$ \\
\hline Did not answer & $1(1.1)$ & $0(0.0)$ & $0(0.0)$ & $1(0.6)$ \\
\hline \multicolumn{5}{|l|}{ Other funding } \\
\hline Aware & $2(2.3)$ & $1(2.5)$ & $2(6.3)$ & $5(3.1)$ \\
\hline Unaware & $84(96.6)$ & $39(97.5)$ & $30(93.8)$ & $153(96.2)$ \\
\hline Did not answer & $1(1.1)$ & $0(0.0)$ & $0(0.0)$ & $1(0.6)$ \\
\hline
\end{tabular}

well known. Although the MUFC was not well known throughout the state, survey respondents indicated that its presence was becoming known through a variety of means such as contacts with foresters or participation in urban and community forestry-related events. Also, for many years, the MUFC was tied to the MFC (they have been operating independently for only a few years).

When examining responses by community size, municipalities with more than 10,000 persons were, unsurprisingly, very familiar with these programs, whereas smaller communities were less so. Interestingly, small- to mid-sized communities lacked much awareness of the Tree City USA, T-21, and Urban and Community Forestry Assistance Challenge Grants programs.

Surveyed communities responded to questions regarding their awareness of potential urban and community funding sources (Table 4). More than one-third of respondents (35.8\%) were aware of funding opportunities through the Transportation Enhancement Tree Planting program (T-21 money), and 28.9\% knew of the Urban and Community Forestry Assistance Challenge Grants.

Disaggregating the data by community size indicated that larger communities were better informed than smaller communities about funding availability for programs such as 
T-21, Federal Cooperative grants, and Challenge grants. Few communities, regardless of size, were aware of other programs such as Partnership Enhancement Monetary Grant program. Nevertheless, tallied responses across all communities indicated little awareness of existing funding sources for adopting urban and community forestry programs (Table 4).

\section{Current Urban Forestry Programs}

This study also asked surveyed communities to describe the kinds of urban and community forestry projects or activities they have participated in the past. It was found that $43.4 \%$ $(n=69)$ of surveyed communities participated in tree planting activities. Others participated in city and community park preservation $(35.8 \%, n=57)$, Arbor Day or Earth Day promotions or celebrations $(23.9 \%, n=38)$, and tree protection or maintenance $(21.4 \%, n=34)$, while others took part in Christmas tree disposal $(20.1 \%, n=32)$.

When examining the responses by community size, communities with populations more than 10,000 had greater participation in these programs compared to smaller communities. Mid-sized municipalities were closer in their responses to smaller communities.

\section{Preferred Communications Media}

The dissemination of information about urban and community forestry is paramount for informing communities about urban and community forestry and updating those partici-

Table 5. Preferred forms of communication media for receiving information on urban and community forestry issues, as indicated by community leaders in Mississippi by community size during 2004 $(n=159)$.

\begin{tabular}{|c|c|c|c|c|}
\hline Inhabitants & $\begin{array}{l}<2,000 \\
\text { count }(\%)\end{array}$ & $\begin{array}{l}2,000-10,000 \\
\text { count }(\%)\end{array}$ & $\begin{array}{l}>10,000 \\
\text { count }(\%)\end{array}$ & $\begin{array}{l}\text { Total } \\
\text { count (\%) }\end{array}$ \\
\hline \multicolumn{5}{|l|}{ Workshops } \\
\hline Prefer & $30(34.5)$ & $19(47.5)$ & $17(53.1)$ & $66(41.5)$ \\
\hline Do not prefer & $57(65.5)$ & $21(52.5)$ & $15(46.9)$ & $93(58.5)$ \\
\hline \multicolumn{5}{|c|}{ Pamphlets or brochures } \\
\hline Prefer & $30(34.5)$ & $16(40.0)$ & $15(46.9)$ & $61(38.4)$ \\
\hline Do not prefer & $57(65.5)$ & $24(60.0)$ & $17(53.1)$ & $98(61.6)$ \\
\hline \multicolumn{5}{|l|}{ Educational kits } \\
\hline Prefer & $30(34.5)$ & $17(42.5)$ & $12(37.5)$ & $59(37.1)$ \\
\hline Do not prefer & $57(65.5)$ & $23(57.5)$ & $20(62.5)$ & $100(62.9)$ \\
\hline \multicolumn{5}{|l|}{ Newsletters } \\
\hline Prefer & $26(29.9)$ & $16(40.0)$ & $11(34.4)$ & $53(33.3)$ \\
\hline Do not prefer & $61(70.1)$ & $24(60.0)$ & $21(65.6)$ & $106(66.7)$ \\
\hline \multicolumn{5}{|c|}{ County forestry agent } \\
\hline Prefer & $20(23.0)$ & $17(42.5)$ & $15(46.9)$ & $52(32.7)$ \\
\hline Do not prefer & $67(77.0)$ & $23(57.5)$ & $17(53.1)$ & $107(67.3)$ \\
\hline
\end{tabular}

pating in activities. This study asked communities how they would like to receive information and other communications about urban and community forestry (Table 5). Workshops (41.5\%), pamphlets or brochures (38.4\%), educational kits (37.1\%), newsletters (33.3\%), and county forestry agent contacts (32.7\%) were the top categories picked. Communities with more than 10,000 people preferred workshops, pamphlets, newsletters, and access to county forestry agents. Mid-sized communities preferred newsletters, and smaller communities were less sure of their preferences.

\section{DISCUSSION}

The $53.7 \%$ response rate for this survey was higher than that of Watson (2004) with 22\%, Schroeder et al. (2003) with 49\%, and Ries (2004) with 51\%, but lower than that of Thompson and Ahern (2000) with 55\%, Treiman and Gartner (2004) with 60\%, and Elmendorf et al. (2003) with $71 \%$. However, there may be a number of reasons contributing to a lower response or interest on the part of some communities. Large cities in Mississippi possess the resources to conduct urban and community forestry programs. Small communities, with small budgets, usually do not have the monetary or technical resources. This result was consistent with studies by Groninger et al. (2002) and Elmendorf et al. (2003). Groninger et al. (2002) found that many rural communities in Illinois lack technical expertise in tree maintenance, do not have an inventory of existing tree resources, and were less likely to participate in state and federal urban and community forestry programs. Elmendorf et al. (2003) reviewed several studies that provided ample evidence that smaller communities in Pennsylvania spent far less than larger communities and have limited or no urban and community forestry programs. This finding may account, in part, for the lower response rate from smaller communities because they did not see urban and community forestry in their purview. In addition, some communities may have felt as though their constituents were not interested in urban and community forestry so they chose not to participate. After all, among all communities that submitted responses, only $13.2 \%$ of community leaders felt that over $60 \%$ of their community thought urban and community forestry was important.

In general, the survey sample of Mississippi's communities indicated that a sizeable number of officials might have a very low or nonexistent level of awareness or interest in urban and community forestry. Thirty-six percent were not aware of the topic of urban and community 
forestry. It may be that their attention to this topic was minimized or diverted due to a lack of resources and/or having to deal with higher-priority issues.

Some Mississippi communities did want to establish urban and community forestry programs, but they lacked the funding resources. Community officials indicated overwhelmingly that funding was the most important issue for initiating and sustaining urban and community forestry projects and/or programs. Mississippi's results were consistent with similar studies in eastern and western Washington state. Studer (2003) found that $64 \%$ of urban forest managers cited greater funding as their most important need. Treiman and Gartner (2004) identified as a major problem the lack of financial resources in northeastern Pennsylvania to support urban and community forestry.

Poor financial support for these programs was a trend common to several regions across the United States. Also, greater efforts in disseminating information on funding opportunities was necessary, given that most Mississippi communities were aware of only a few national funding programs. Participation in statewide or local programs was minimal. Communities facing funding obstacles for implementing urban and community forestry programs could potentially pool their limited resources and sponsor active participation by local community groups. Numerous communities engaged in tree planting activities through organizations such as the Boy Scouts, garden clubs, school groups, and volunteers.

Urban and community forestry outreach has helped communities become more familiar with recreational, wildlife, soil, and air-quality benefits of urban and community forestry, but less so for its other benefits such as fire protection, water quality, social issues, and carbon sequestration. Many of these are vitally important issues for communities, and the lack of association with urban and community forestry presents an opportunity to initiate and direct outreach activities.

Although some Mississippi communities may be aware of the benefits of implementing urban and community forestry programs, future communication efforts need to focus on contacting more communities and employing different venues for transferring urban and community forestry technologies and information. The overall lack of awareness and number of survey questions that went unanswered indicated that there exists an enormous challenge and, yet, an exciting opportunity to promote urban forestry in Mississippi. Suggested venues for technology and information transfer by community leaders include workshops, pamphlets/brochures, newsletters, educational kits, newsletters, county forestry agents, and videos. Products can then be disseminated through various organizations (e.g., MFC, MUFC, and Mississippi State University) as well as journals, newspapers, Web links, and other media.

\section{CONCLUSIONS}

This study was a first attempt at evaluating the knowledge levels and information needs of Mississippi's large and small municipalities. In general, there was interest in urban and community forestry programs in Mississippi on the part of large and small communities alike. A major obstacle to adopting and implementing these programs was the lack of adequate funding. Budgetary constraints have limited urban forestry programs throughout the state, especially for smaller communities. In addition, many communities failed to adopt urban and community forestry programs because they lack the necessary expertise on their staff to address existing situations and problems with program administration. Despite these obstacles to program adoption, communities have expressed a desire for information on technical issues and fundraising opportunities to be provided in a variety of venues, such as pamphlets, books, videos, e-mail, and newsletters.

Future research endeavors should focus on evaluating the impacts of the preferred communication media outlined in this study. Such research could serve as the basis for developing an efficient system for transferring information technology to different-sized communities. In addition, case studies should be conducted in relevant Mississippi communities to document lessons learned from various programs as a guide for communities interested in establishing urban and community forestry programs. Finally, acquiring the type of information gleaned from this study should encourage any state desiring to promote urban and community forestry to undertake a similar assessment of their communities.

\section{LITERATURE CITED}

Dillman, D.A. 2000. Mail and Internet Surveys: The Tailored Design Method (2nd ed.)Wiley, New York, NY. 464 pp.

Dwyer, J.F., E.G. McPherson, R.A. Rowntree, and H.W. Schroeder. 1992. Assessing the benefits and costs of the urban forest. Journal of Arboriculture 18(5):227-234.

Elmendorf, W.F, V.J. Cotrone, and J.T. Mullen. 2003. Trends in urban forestry practices, programs, and sustainability: Contrasting a Pennsylvania, U.S., study. Journal of Arboriculture 29(4):237-248.

Grey, G.W. 1978. What should be the role of state government in municipal arboriculture--urban forestry? Journal of Arboriculture 4(3):71-72.

Groninger, J.W., D.D. Close, and C.M. Basman. 2002. Can small, rural communities practice urban forestry? Journal of Forestry 100(1):23-28.

Johnson, C. 1982. Political $\&$ administrative factors in urban-forestry programs. Journal of Arboriculture 8(6):160-163.

Maco, S.E., and E.G. McPherson. 2002. Assessing canopy cover over streets and sidewalks in street tree populations. Journal of Arboriculture 28(6):270-276. 
McPherson, E.G. 1996. Research in Urban Forestry. Forest Research West, USDA Forest Service Pacific Southwest Research Station, Albany, CA.

Miller, R.W., and T.R. Bate. 1978. National implications of an urban forestry survey in Wisconsin. Journal of Arboriculture 4(6):125-127.

Reis, P.D. 2004. Urban and Community Forestry in Oregon: Results of the 2004 City Survey. http://egov.oregon.gov/ ODF/URBAN_FORESTS/docs/04SurveyRptfinal.pdf (accessed 12/1/05).

Schroeder, H.W., T.L. Green, and T.J. Howe. 2003. Community tree programs in Illinois, U.S.: A statewide survey and assessment. Journal of Arboriculture 29(4):218-225.

Studer, N. 2003. Urban forest program development in Washington state municipalities, pp. 21-23. In Kollin, C., (Ed.). 2003 National Urban Forest Conference Proceedings, 17-20 September 2003, San Antonio, TX. American Forests, Washington, DC.

Tate, R.L. 1982. Applying for federal funding grants for urban tree management activities. Journal of Arboriculture 8(4):107-109.

Thompson, R.P., and J.J. Ahern. 2000. The State of Urban and Community Forestry in California. Technical Report No. 9. California Department of Forestry and Fire Protection, Urban Forestry Program, San Luis Obispo, CA. 48 pp.

Treiman, T., and J. Gartner. 2004. Community forestry in Missouri, U.S.: Attitudes and knowledge of local officials. Journal of Arboriculture 30(4):205-213.

Watson, W.T. 2004. Status of Urban Forestry in the South, Final Report. Department of Forest Science, Texas A\&M University, College Station, TX.
Acknowledgments. This manuscript is publication No. FO295 of the Forest and Wildlife Research Center, Mississippi State University.

Stephen C. Grado (corresponding author)

Professor, Department of Forestry

Forest and Wildlife Research Center

Box 9681

Mississippi State, MS 39762, U.S.

Donald L. Grebner

Associate Professor, Department of Forestry

Forest and Wildlife Research Center

Box 9681

Mississippi State, MS 39762, U.S.

Marcus K. Measells

Research Associate, Department of Forestry

Forest and Wildlife Research Center

Box 9681

Mississippi State, MS 39762, U.S.

Amanda L. Husak

Research Associate

701 SW Chaucer Circle

Lawton, OK 73505, U.S. 
Résumé. Il y a un besoin pour déterminer les niveaux de connaissance et de participation des élus locaux et des autres planificateurs des programmes de foresterie urbaine au sein des villes et des localités rurales. Les objectifs de ce projet étaient d'identifier les niveaux d'implication et d'intérêt, actuel et futur, au sein des petites et grandes communautés du Mississipi en regard des programmes et de l'assistance en foresterie urbaine. Un questionnaire d'enquête a été envoyé par la poste à 296 communautés du Mississippi. Cent cinquante-neuf ont été retournés, soit un taux de réponse de 53,7\%. En général, l'échantillonnage des communautés indique qu'il y a un nombre assez considérable de personnes officielles qui n'ont que peu voire aucun intérêt ou sensibilité en regard de la foresterie. Parmi les communautés du Mississipi qui désiraient implanter des programmes de foresterie, urbaine ou rurale, la plupart ont mentionné un manque de ressources financières comme motif pour ne pas initier de nouveaux projets ou soutenir ceux existants. De plus grands efforts pour disséminer de l'information quant aux opportunités de financement sont nécessaires, et ce du fait que la plupart des communautés du Mississipi sont seulement au courant de quelques-uns des programmes nationaux. Le niveau de participation aux programmes locaux ou à l'échelle de l'état était limité. Sans une bonne information et une source de financement fiable, les communautés sont limitées pour entreprendre une planification systématique et mettre en place des programmes pour la ressource arbre au sein de leur communauté. De plus, la délivrance d'informations vers les communautés pour faire apprécier de la part du public la ressource forestière urbaine est critique.

Zusammenfassung. Es besteht ein Interesse, das Wissen und den Grad der Teilnahme von gewählten öffentlichen Vertretern und anderen kommunalen Planern an urbanen und kommunalen Forstprojekten zu bestimmen. Die Ziele dieser Studie bei kleinen bis großen Kommunen in Mississippi waren es, die vergangenen und gegenwärtigen Engagements und zukünftigen Interessen für Forstprogramme und Assistenz zu identifizieren. An 296 Kommunen wurde per Post ein Fragebogen geschickt. 159 Fragebögen kamen zurück, die Rate betrug 53,7 \%. Allgemein zeigten die Bögen, dass eine große Zahl von Offizielen wenig oder kein Bewusstsein oder Interesse an urbaner und kommunaler Forstwirtschaft hat. Unter den Gemeinden in Mississippi, die Forstprogramme etablieren wollten, schrieben die meisten, dass sie kein Geld hätten, um Programme zu initiieren oder zu unterstützen. Um Informationen über Geldbeschaffung besser zugänglich zu machen, sind größere Anstrengungen nötig, nur wenige Gemeinden waren vertraut mit den staatlichen Förderprogrammen. Die Teilnahme an nationalen oder lokalen Programmen war gering. Ohne gute Information und sichere Geldgeber sind die Gemeinden eingeschränkt in der systematischen Planung von Baumförderprogrammen. Darüber hinaus ist die Akzeptanz von urbaner Forstwirtschaft bei der Bevölkerung und der Informationsfluss dahin sehr kritisch.

Resumen. Existe la necesidad de determinar los niveles de conocimiento y participación de los oficiales elegidos localmente y de otros planificadores de programas de silvicultura urbana y de la comunidad. Los objetivos de este proyecto fueron identificar la participación pasada y presente y los niveles de interés futuro por los programas y asistencia de silvicultura urbana entre las comunidades del Mississippi. Una encuesta postal fue enviada a 296 comunidades del Mississippi. Se recibieron 159 encuestas resueltas, una tasa de respuesta del $53.7 \%$. En general, la muestra de la encuesta de las comunidades del Mississippi indicó que un número considerable de oficiales tiene poco o ningún conocimiento o interés en la silvicultura urbana y de la comunidad. Entre las comunidades del Mississippi que querían establecer programas de silvicultura urbana y de la comunidad, la mayoría citaron la escasez de fondos como la razón por la cual no inician proyectos o no sostienen programas existentes. Es necesario un mayor esfuerzo para diseminar información sobre oportunidades de financiamiento, dado que la mayor parte de las comunidades del Mississippi sólo conocían unos cuantos programas nacionales. La participación en programas estatales o locales fue mínima. Sin buena información y financiamiento fiable, las comunidades se ven limitadas para llevar a cabo una planeación sistemática y programas asociados para los recursos arbóreos en su comunidad. Adicionalmente, es indispensable repartir efectivamente información entre las comunidades para aumentar el reconocimiento público hacia los recursos del bosque urbano. 